\title{
The June 1948 Yugoslav-Soviet Crisis: The Italian and American Political Perception and its Consequences over the Trieste's Dispute
}

\author{
Dr. Gabriele Vargiu \\ Sapienza Università di Roma, Italia \\ gabriele.vargiu@gmail.com
}

Doi:10.5901/ajis.2013.v2n9p791

\begin{abstract}
The paper intends to offer a systematic and well-rounded insight into the consequences of the Yugoslav-Soviet diplomatic crisis in relation to the territorial dispute between Rome and Belgrade for the control of Trieste and its immediate hinterland. Via a comparative analysis of both the relevant Italian and Anglo-Saxon historiographies, integrated with a study of the memoirs of the most prominent political figures involved, the research seeks to thoroughly stress the realist rather than ideological reasons which triggered the breakdown of the socialist bloc. Such a preparatory result precedes the reconstruction of the different approaches used by the Italian and American foreign policies in order to manage the developments affecting the international, regional and local strategic scenarios following the isolation of Tito's regime. Lastly, the work seeks to give a solution to the queries in the title comparing and evaluating the effects over Trieste's political fate which stemmed from the political responses adopted by the Western and Eastern governments during the specific historical circumstances.
\end{abstract}

Keywords: Trieste, Cold War, Italy, Yugoslavia, 1948

\section{An introduction to the historical context}

Being in the meantime a subject of political and ideological debate in Italy, a source for a thirty-year long controversy with the neighboring Yugoslavia, as well as one of the first breeding grounds for the Cold War confrontation, the so-called Trieste question represented along decades a starting point for evaluating both the reconstruction of Italian foreign policy during the republican era and the consolidation of a bipolar struggle following the end of the Second World War.

Throughout its long evolution which concluded with the Treaty of Osimo, the dispute over the Giulian city experienced periods of increasing bilateral and international tension and phases where all political protagonists involved lost interest and momentum for the issue.

Diego De Castro's monumental work "The Trieste Question" summarizes such feature dividing its historical account between a 'static phase' - more or less corresponding to the events which occurred during the 1940s - and a 'dynamic phase' presenting difficult bilateral talks preceding the London Memorandum entente (De Castro 1980), a prelude for a long freeze in respective national claims which lasted until 1975.

Nonetheless, the short lapse of time running between the end of 1947 and the spring of 1948 is arguably the only one where all the fields of interest - national, bilateral and global - intersecting and influencing one another completely.

From the Italian point of view the period saw the government and public opinion cultivating great expectations for a quick annexation of the whole Free Territory of Trieste, a consequence of the fresh, as well as ephemeral, pro-Italian policy promoted by the Western powers in correspondence to elections which would have chosen the national positioning inside the Cold War strategic scheme.

The assertiveness towards Rome started to fade away since the following June: the containment reasons which previously explained such an attitude began to impose a shift of the American, British and French stances on a neutral equidistance from both the contenders. The triggering event was an unforeseen diplomatic socialist breakdown between Tito and Stalin, an event which spawned significant effects on the Trieste's political fate.

\subsection{At the roots of the Yugoslav-Soviet diplomatic breakup}

According to Stalin's declaration regarding the ideological degeneration which would have compounded the Yugoslav socialism, exposed into the Czechoslovakian journal Rude Pràvo on 28 th June (Monzali 2004), the causes of the crisis between Moscow and Belgrade were brought down to a mere theoretical contrast which appears to be strongly spurious. 
Conversely, the diplomatic breakdown seems to lie on much more pragmatic considerations which will be the focus of this chapter.

First and foremost, the origin of the dispute between the former allies can be explained by a different interpretation of the changes which involved the international relations system in the aftermath of the German capitulation of May 1945. As never before in Modern History the polarization of the military force and the prestige around the American and Soviet superpowers resulted in an automatic downgrading of the remaining States to a subordinate position, jeopardizing their political capabilities beyond the internal landscape. More than in the proud Western chanceries, such a dynamic was immediately perceived in the institutionally fragile Eastern Europe's Countries which had been freed and then occupied by the Red Army. Cold War international politics would have been radically different from the multipolar and 'balance of power'-centered system established in Europe during the seventeenth century.

Amid this overall strategic retreat of the Eastern States, Yugoslavia distinguished itself as a sui generis case thanks to its specific wartime experience - the sole country in the area which had managed to throw the Nazi-fascist forces out of its borders without any significant external aid - and the consolidation of an ambitious and charismatic leadership which could count on broad popular approval.

Proving wrong what traditional historiography affirmed, the reason for the dispute did not seem to be connected to a supposed leftist deviationism of the Yugoslav Communist Party (Halperin 1958), the Soviet expansionism (Auty 1970), the lack of a Ussr's logistic support during the war (Ulam 1952) or, from another point of view, the military support granted at the end of the conflict, according to some an attempt to 'colonize' the Titoist army (Armstrong 1951). On the contrary, the explanation should be researched in the dynamic foreign policy promoted by Marshall Tito and his deputy Edvard Kardelj aiming at imposing their hegemony over the whole Balkan Peninsula.

The newborn Yugoslavia, risen from victory in the war, expressed annexationist claims against almost all the States in the area. Albania, freed from Italian control, would be absorbed in order to play down the dangerous ethnic tensions which had run through the Kosovo province since the first decades of the century. Bulgaria would rejoin its Balkan sister in the name of political unity among the Southern Slavic peoples. Greece upset by the civil war between monarchists and communists should renounce to the internal Macedonia until the shores of Salonika, opening Yugoslavia to the Aegean Sea. At the same time, Austria should accept the Yugoslav annexation of the southern part of Carinthia, including Klagenfurt (Knight 2000). Not least, Belgrade did not give up its claims to Trieste, occupied in March 1945 and evacuated after forty days following Western and Soviet diplomatic pressure. Generally, a wide federative project aspiring to elevate Yugoslavia into a preeminent international position which appeared hardly compatible with the Soviet strategic grand vision aiming at the satellization of the whole of Eastern Europe.

In spite of this, Tito's evident foreign goals did not represent a stumbling block for its relations with Moscow during the immediate aftermath of the war. Though the conclusion of a Treaty of friendship and mutual assistance ${ }^{1}$, integrated with some important economic and customs agreements, had led Albania inside the Yugoslav sphere of influence since the summer 1946, the successful Titoist communism still appeared as a model for the other European People's Republics praised and defended by Soviet Politburo. Yet in September 1947, such a good relations were substantiated by the cooperative spirit surrounding the first Cominform reunion, proof which casts shadows on Kardelj's memorialistic affirmations, for whom the global coordination body for communist parties had been established in order to delegitimize Belgrade's political regime (Kardelj 1982).

On the contrary, an actual change in the Soviet attitude toward its closer ally occurred later as a consequence of the Yugoslav reticence to renounce to its ambitious plan for a Balkan federation.

During 1947 Tito signed a friendship treaty with Bulgaria without making Stalin aware of it, while on $20^{\text {th }}$ March 1948, he negotiated with the Albanian leader Enver Hoxha the conveyance of the Kocha base under the Yugoslav authority, as a response to the supposed hostile intention cultivated by Greek 'monarch-fascists' (Hoxha 1982). Moreover, in relation to the Greek problem, he was preparing a military intervention oriented at backing the internal communist guerrilla in the northern part of the Country.

The switch from a policy of claims to its factual actualization is arguably the turning point which led to diplomatic breakdown on the following June (Gibianskii 1982). On 10 th February 1948 Stalin summoned both the Yugoslav and Bulgarian representatives for a confrontation over their Balkan foreign policies where, in spite of the reassurances for a closer cooperation, the diplomatic rift had not completely healed. Tito's determination to threaten war against Greece and

\footnotetext{
1 United Nations, Treaty of Friendship and Mutual Assistance between the Federative People's Republic of Yugoslavia and the People's
} Republic of Albania (9 July 1946). Treaty Series, 1, 1946-1947, 88-92. 
his renewed willingness to send troops into Albanian territory pushed the Soviet Union to withdraw its military aid from Yugoslavia on $18^{\text {th }}$ March, triggering harsh protests in Belgrade. Progressively what started as a dispute about the distribution of power inside the Eastern European arena took on the shape of a Soviet ideological trial against the deviationist application of Marxism-Leninism by JCP. In June contrasts got worse and worse until the definitive break off.

Moving the reasons of the crisis on a theoretical level Stalin imposed Tito a field of battle that condemned him to defeat, obtaining an unquestionable short-term victory. Having moved away from its traditional Bulgarian and Albanian allies - lately turned into the most resolute backers of Stalinism - Yugoslavia was suddenly forced into a state of diplomatic isolation which put into question even the survival of Titoist leadership.

\section{Italian and Western responses to the changes into the strategic scenario}

News of Soviet 'excommunication' against JCP caught Italian diplomacy and the whole Western bloc unprepared. Although some first signs had been noticed inside the American Department of State, the possibility of such a drastic crisis inside the Socialist world was generally perceived as a remote hypothesis. Conversely, starting from 30th June 1948 the capitalist world was obliged to face up to an unforeseen evolution of the strategic scenario, a change that was likely to produced important consequences over the bipolar balance of power which was taking shape in the second half of the 1940s.

Eloquently, George Kennan (Kennan 1957) summarized such a transformation affirming that the crisis put the United States in front of the fresh dilemma of what stance should be assumed in relation to a State which was moving radically away from the Soviet power without rejecting the revolutionary aims of Marxism. Whatever the choice, it could have represented a undeniable precedent for every subsequent defection which may have occurred inside the Soviet sphere of influence and become a prelude for open conflict with Moscow.

From Washington's point of view the break down became tactically useful from a military perspective because it moved back by some hundreds of kilometers the frontier of the so-called 'iron curtain', complicating the hypothetic advance of the Red Army throughout the Padan plain and the coasts of the French Provence, in other words the southern plan of invasion that the Soviets would have followed in case of war.

Moreover, an independent and Western-oriented Yugoslavia would have meant an evident rebuttal of the supposed incompatibility between political regimes ideologically opposed, a triumph of political realism against a dangerous manichaeist vision of international relations and an incitement which could lead other Eastern States to emulate Belgrade, weakening the Ussr's European and global positioning (Lees 1997). Such positive spill over were counterbalanced by the internal and external reactions that the diplomatic reconciliation was about to produce. In all likelihood, defending Tito and its defiance against the Soviet political interferences would have caused a sense of disorientation for a public opinion which would have hardly understood what substantial differences between Soviet and Yugoslav dictatorships could push the Truman administration into undertaking such a policy. Not least, a possible future tout court integration of Belgrade inside the Western bloc would have surely represented a provocation capable of starting an inexorable military escalation, rushing the contenders into a Third World War.

In spite of the radical consequences which could stem from it, the American establishment manage to weight up quickly pro and counter factors offered by the new international crossroads, suggesting what attitude should be adopted. As soon as $29^{\text {th }}$ June R. Borden Reams, from the American embassy in Belgrade, communicated to the Secretary of State Mashall the fallout which occurred in the Yugoslav capital following the Stalinist diktat, urging an immediate American declaration supporting the political independence of the small nations ${ }^{2}$. Reams, as well as his colleague Charles Stephan, had noticed weeks before how several disputes were jeopardizing the relations between Stalin and his closer ally, connecting those signals to the Soviet unwillingness to accept the preeminent international role which Tito claimed for his Country. Also, both the officials, were aware of the widespread popular approval surrounding the Yugoslav leader: as a result, any serious Soviet intervention aimed at ousting him from power would have probably met strong public opposition. Along with the American military top brass in Europe, they suggested a conciliatory approach in order to exploit the unexpected systemic benefits which could flow from the crisis (Stephan 1982).

Embracing Kennan's evaluations, forthwith the United States adopted a strategy which hailed the renewed Yugoslav autonomy and set off a new phase of bilateral cooperation though limited to the economic domain: any other kind of cooperation which could have provoked internal protests or external reprisals would be excluded.

\footnotetext{
2 Reams to Marshall, 29th June 1948, RG 59, no. 789, 860H.00/6-2948.
} 
Such guidelines, included in July inside the eighteenth National Security Council policy paper (NSC 18), inspired America's conduct toward the Titoist regime for several years. The huge loans coming from Washington -1.2 billion dollars mainly used to finance the military expenditures - enable the Socialist State to get through the economic isolation imposed by its former ally; at the same time, Tito's survival represented a positive result for the containment strategy, as well as a striking setback to the process of Stalinization in Eastern Europe (Bucarelli 2008; Lees 1978; Lees 1997).

Thus, while the careful assessment of the evolution inside the strategic scenario led the United States to a radical reappraisal of its stance to Belgrade, the same events had been read by the Italian government from its different national and local point of view. Excepting for a comforting removal of a direct Soviet menace from the eastern boundaries, from Rome's perspective the Tito-Stalin split caused serious negative consequences for the solution to the Trieste question, conversely a secondary issue for Washington. As the relevant Italian historiography affirms, such effects could have assumed positive traits if they had been promptly exploited. During the immediate aftermath of Stalin's 'excommunication' the isolation, disorientation and the need for a political agenda focused on the safeguard of the goals obtained following 1945 made Yugoslavia weak enough that Italy could have claimed what just few months before the Western powers had affirmed to be Italian for traditional and legal rights: the whole territorial area included into the Free Territory of Trieste (De Castro 1980).

In spite of this, Italy wasted the opportunity that it had been seeking for a longtime and, as a result, it can be shared the evaluation of whom mistrusted about the existence of an actual connection between the national strategy adopted in order to contrast Belgrade and the aims that the Italian foreign policy declared to pursue (Bianchini 1995).

Even according to Carlo Sforza, Italian Foreign Minister between 1947 and 1951, Palazzo Chigi's approach toward its Adriatic neighbor had no substantial change (Sforza 1954). On the contrary, Kardelj and the Yugoslav diplomatic core proved themselves able to react to the unfavorable historical contingency, avoiding that more and more frequent border clashes with the other People's Republics turned into open conflicts, facing the Cominform negative propaganda from the Vittorio Vidali-led Communist Party of the FTT (Gozzini and Martinelli 1998, Pirjevic 1995) and promoting a policy of boldness in respect to the Trieste dispute.

On 28th July 1948 the Yugoslav delegation at the United Nations presented to the Security Council a complaint for the pro-Italian behavior shown by the Allied Military Government in FTT zone A. The protest was linked to the economic and customs agreements approved in May which had considerably increased Italian leverage on the sector of the buffered State under Anglo-Saxon control. Nevertheless, the request for an annulment of such agreements was rejected by the Council, recalling the overall compatibility between those and the Italian peace treaty. It should be remarked how the Western power, namely the British delegate sir Cadogan, stressed that the use of a coercive force by the Yugoslav army in FTT zone B represented a far more serious violation of the 1947 treaty than any commercial deal (1980).

Protests accompanied a bid to restart negotiations to nominate a governor, an issue left unsolved since the institution of FTT and which mirrored the almost unanimous will to keep the nature of the juridical status of the State provisional. This move was part of the strategy chosen by Yugoslavia in response to its condition of international isolation: provoking friction among the Western coalition and the Soviet Union so preventing a revision of the Paris clauses in favor of Italy.

The evaluation appeared mistaken on two counts. On the one hand possible Kremlin support for a review of the Italian peace treaty seemed highly unlikely because strategically pointless: Stalin hadn't gone along with the West in its $20^{\text {th }}$ March tripartite declaration even when, on the eve of the $17^{\text {th }}$ April elections, it could have increased the communists' chances of victory. Following the June split, such a snub would have incited Tito to fully align himself with the Western camp (Clissold 1975). On the other hand concerns about an actual commitment by the Allies for the enforcement of the Tripartite Declaration proved to be unfounded due to the American willingness to defend Tito's regime defection from the Soviet bloc.

\section{Conclusions}

The progressive rapprochement between Yugoslavia and the United States at the end of the summer of 1948 put an end to the most magmatic and uncertain phase of the Trieste conflict: in a few months the balance of power and the diplomatic stances of all the States involved in the issue had been radically transformed.

For both Washington and Moscow the permanent nature of the split between Stalin and Tito - as well as the proven capability of the latter to foil all Soviet attempts to destabilize its leadership (Ceh 2002) - turned the Giulian capital from a dangerous Cold War frontier to a territorial squabble affecting only the States directly involved. As a consequence the Allied military forces operating in Zone A - up to May 1948 as a guarantee against Yugoslav expansionism - became 
an unwanted foreign presence in a territory administered by the Italians, which they could have not leave before the conclusion of the bilateral dispute.

For both Rome and Belgrade the period running from the beginning to the middle of 1948 marked a fluctuating reversal of their respective expectations over the future of the contested city, which ended in a meaningful return to the status quo ante. While exploiting the delicate electoral turning point, Italy had managed to gain favor with The West for a positive solution to the disagreement, the distancing of Yugoslavia from the socialist bloc had made even more ephemeral a promise, which could not be honored without coercive means. Italy, which could have obtained important concessions from negotiations during the Yugoslav isolation period, stayed anchored to a position of sitting on the fence. Alcide De Gasperi, Italy's most prominent political figure after the Second World War, kept on following a rock-like opposition towards any real search for a modus vivendi with Tito which would have preceded the conclusion of the territorial dispute, even if the achievement of the second goal was subordinated to the fulfillment of the first (Pastorelli 1995).

The 'city without peace' (Vidali 1982) rejoined the Peninsula only after prolonged bilateral talks which ratified Italy having to definitively renounce to the southern sector of the dissolved Free Territory of Trieste.

\section{References}

Armstrong, H. (1951). Tito and Goliath. New York: The Macmillan Company.

Auty, P. (1970). Tito: a Biography. London: Longman.

Bianchini, S. (1995). I mutevoli assetti balcanici e la contesa italo-jugoslava, in M. Galeazzi (ed.), Roma-Belgrado: gli anni della guerra fredda. Ravenna: Longo editore.

Bucarelli, M. (2008). La "questione jugoslava" nella politica estera dell'ttalia repubblicana (1945-1999). Rome: Aracne.

Ceh, N. (ed.) (2002). U.S. Diplomatic Records on Relations with Yugoslavia during the Early Cold War, 1948-1957. New York: East European Monographs.

Clissold, S. (1975). The Postwar Period: Friendship and Friction, in S. Clissold (ed.), Yugoslavia and the Soviet Union, 1939-1973. London: Oxford University Press.

De Castro, D. (1980). La questione di Trieste. L'azione politica e diplomatica italiana dal 1943 al 1954. Trieste: Lint.

Gibianskii, L. (1997). The Soviet-Yugoslav Split and the Cominform, in N. Naimark \& L. Gibianskii (eds.), The Establishment of Communist Regimes in Eastern Europe, 1944-49. Boulder, CO: Westview Press.

Gozzini, G. \& Martinelli, R. (1998), Storia del Partito comunista italiano. Dall'attentato a Togliatti all'VIII congresso. Turin: Einaudi.

Halperin, E. (1958). The Triumphant Heretic: Tito's Struggle Against Stalin. Portsmouth: Heinemann.

Hoxha, E. (1982). The Titoists: Historical Notes. Tirana: Nëntori Publishing House.

Kardelj, E. (1982). Reminiscences: The Struggle for Recognition and Independence: The New Yugoslavia, 1944-1957. London: Blond \& Briggs.

Kennan, G.F (1957). Memoirs: 1925-1950. Boston: Little Brown.

Knight, R. (2000). Ethnicity and Identity in the Cold War: the Carinthian Border Dispute, 1945-1949. International History Review, 2.

Lees, L.M. (1997). Keeping Tito Afloat: The United States, Yugoslavia and the Cold War, 1945-1960. University Park: Pennsylvania State University Press.

Lees, L.M. (1978). The American Decision to Assist Tito, 1948-1949. Diplomatic History, 4.

Monzali, L. (2004). La questione jugoslava nella politica estera italiana, in F. Botta, \& I. Garzia (eds.), Europa Adriatica. Milan: FrancoAngeli.

Pastorelli, P. (1995). Origine e significato del Memorandum di Londra. Clio, 4.

Perovic, J. (2007). The Tito-Stalin Split. A Reassessment in Light of New Evidence. Journal of Cold War Studies, 9, 2.

Pirjevec, J. (1995). Mosca, Roma e Belgrado (1948-1956), in M. Galeazzi (ed.), Roma-Belgrado: gli anni della guerra fredda. Ravenna: Longo editore.

Sforza, C. (1954). Cinque anni a Palazzo Chigi: la politica estera italiana dal 1947 al 1951. Rome: Atlante.

Stephan, C.G. (1982). The Emergence of the Soviet-Yugoslav Break: A Personal View from the Belgrade Embassy. Diplomatic History, 6.

Vidali, V. (1982). Ritorno alla città senza pace. II 1948 a Trieste. Milan: Vangelista.

Ulam, A. (1952). Titoism and the Cominform. Cambridge: New Haven. 